
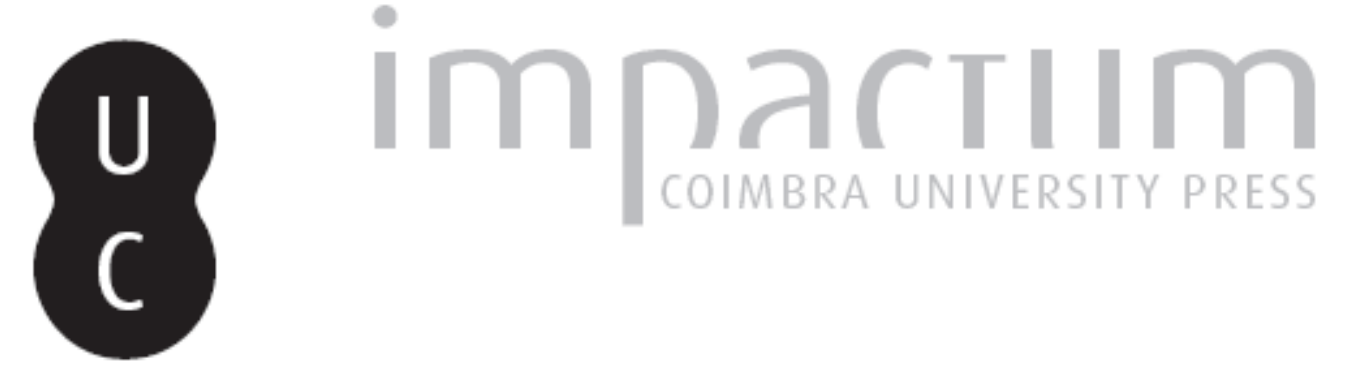

\title{
"Missão histórica" e o "papel dos intelectuais" na filosofia da cultura de Bento de Jesus Caraça: do momento da consciência à consciência do momento
}

\author{
Autor(es): $\quad$ Dias, Luís Augusto Costa
}

Publicado por: Imprensa da Universidade de Coimbra

URL

persistente:

URI:http://hdl.handle.net/10316.2/43724

DOI:

DOI:https://doi.org/10.14195/2183-8925_24_11

Accessed : $\quad$ 26-Apr-2023 16:27:26

A navegação consulta e descarregamento dos títulos inseridos nas Bibliotecas Digitais UC Digitalis, UC Pombalina e UC Impactum, pressupõem a aceitação plena e sem reservas dos Termos e Condições de Uso destas Bibliotecas Digitais, disponíveis em https://digitalis.uc.pt/pt-pt/termos.

Conforme exposto nos referidos Termos e Condições de Uso, o descarregamento de títulos de acesso restrito requer uma licença válida de autorização devendo o utilizador aceder ao(s) documento(s) a partir de um endereço de IP da instituição detentora da supramencionada licença.

Ao utilizador é apenas permitido o descarregamento para uso pessoal, pelo que o emprego do(s) título(s) descarregado(s) para outro fim, designadamente comercial, carece de autorização do respetivo autor ou editor da obra.

Na medida em que todas as obras da UC Digitalis se encontram protegidas pelo Código do Direito de Autor e Direitos Conexos e demais legislação aplicável, toda a cópia, parcial ou total, deste documento, nos casos em que é legalmente admitida, deverá conter ou fazer-se acompanhar por este aviso.

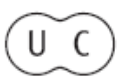



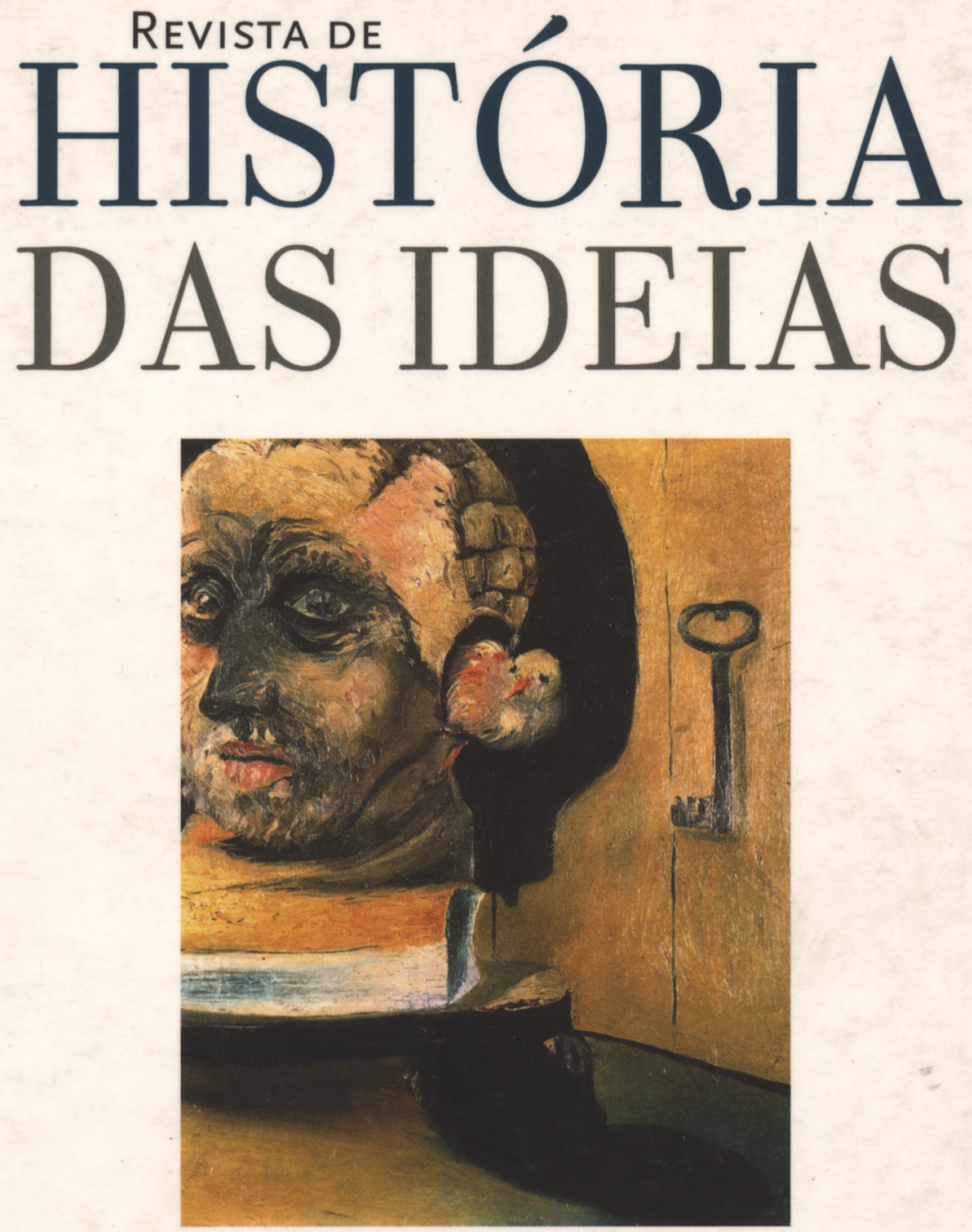

OS INTELECTUAIS E OS PODERES

Volume 24, 2003

INSTITUTO DE HISTÓRIA E TEORIA DAS IDEIAS

Faculdade de Letras da Universidade de Coimbra 


\section{“MISSÃO HISTÓRICA" E O “PAPEL DOS INTELECTUAIS" NA FILOSOFIA DA CULTURA DE BENTO DE JESUS CARAÇA Do momento da consciência à consciência do momento}

\section{Prefácio a uma proto-história dos modernos intelectuais portugueses}

Seria interessante - conquanto não caiba naturalmente no estrito âmbito destas linhas, senão em esboço introdutório, propor uma génese da história contemporânea dos intelectuais portugueses - apurar como, aí pelo último quartel do século XIX, uma celebrada obra ficcional de Eça de Queirós poderá representar a primeira peça de um verdadeiro processo do homem de letras oitocentista. No esteio imediato da noção voltairiana de "gens de lettres" inscrita na famosa Enciclopédia das Luzes, a designação de publicista generalizada nos nossos meios liberais, tão difusa quanto duradoura, configurou o paradigma liberal e romântico do intelectual num tempo em que, conforme a perspectiva ideal do sujeito burguês e homem ${ }^{(1)}$ e segundo a muito celebrada fórmula inaugural de Garrett, "os poetas fizeram-se cidadãos".

No essencial, a proeminência do homem de letras na sociedade não derivava de uma marca distintiva conferida especificamente pela actividade intelectual ou por qualquer dimensão colectiva de um papel

* Investigador do Centro de Estudos Interdisciplinares do Século XX-Ceis20, da Universidade de Coimbra.

(1) Ver Jürgen Habermas, L'Espace Public. Archéologie de la Publicité Comme Dimension Constitutive de la Société Bourgeoise, Paris, Payot, 1997, pp. 64-66. 
social prática ou simbolicamente desempenhado pelo conjunto dos membros desse grupo, mas antes da sua condição de burguês culto em geral e considerado na sua individualidade. E esse era o estatuto de notável que comungava indistintamente com outros estratos sociais na esfera pública burguesa. Dito de outro modo, numa expressão que contém os conceitos básicos da época: "A opinião pública a respeito de homens, é o maior ou menor interesse que os cidadãos ilustrados tomam por certos indivíduos mais notáveis dentre eles"(2).

E essa opinião pública, antes de mais ilustrada, incluía, pois, na escala superior do modelo simbólico construído em torno desse estatuto difuso dos notáveis, um agregado heterogéneo de burgueses cultos, para lá daqueles que tradicionalmente desempenhavam funções intelectuais. Neste meio, o que hoje designamos por intelectual ascendia, para o conjunto da época liberal clássica, ao estatuto de notável pelos motivos gerais a que podia aceder igualmente o negociante ou o lavrador, o magistrado ou o funcionário da administração, o militar ou o eclesiástico - isso mesmo afirma ainda Garrett numa síntese dos quadros em que, aos olhos do que designa por opinião pública, deveria distinguir-se o cidadão no sentido pleno e, então, mais elevado do termo, isto é o burguês proprietário, mas, acima de tudo, o homem culto: "Militares poucos; negociantes alguns, mas de conhecido crédito e honra; magistrados os que não tiverem feito casa nos lugares, e estiverem mal com os seus procuradores; empregados em geral os que não comerciarem em seus empregos; eclesiásticos os prudentes e exemplares; lavradores abastados; enfim produtores de toda a espécie" ${ }^{\prime \prime}$.

Ainda com a tendência para o relevo público que vieram a assumir as figuras do poeta e do artista até final do século XIX português, creio não se ter alterado no essencial um modelo de intelectual referenciado na categoria do escritor público - aquele que conferia à generalidade dos indivíduos notáveis o exemplo de honra, prudência e independência de espírito: mais do que arauto, era o profeta das causas públicas, numa relação com a colectividade que derivava da posição privilegiada de

(2) Almeida Garrett, "Carta de Guia para Eleitores [...]" (1826), in Obra Política. II. Doutrinação da Sociedade Liberal (1824-1827), Lisboa, Estampa, 1991, p. 131.

(3) Idem, ibidem, pp. 138-139. 
produtor cultural na medida em que a cultura, especialmente literária, constituíra, até então, a porta de acesso à intervenção política ${ }^{(4)}$. Como indivíduo isolado, a relação do intelectual com o outro seguiu as normas do primado do $\mathrm{eu}$, até ao egotismo e ao diletantismo com que se afirmava individualmente: até final do século XIX português - com a excepção, aliás confirmadora, da mobilização nacionalista em torno da questão do ultimatum de 1890 -, o intelectual romântico e liberal, recrutado especialmente no campo literário (e, no período final da Regeneração, ascendendo à carreira política pelo corredor do jornalismo $\left.{ }^{(5)}\right)$, não deixou de agir num quadro de predominância individual ou de agregação meramente corporativa e de circunstância. $O$ resultado, válido para a acção de gerações de escritores que seguiram essa famosa "vontade de morrer" aberta por Alexandre Herculano ${ }^{(6)}$, foi esse espécime de petit bourgeois retiré rotulado ingénua e genialmente por Eça de Queirós, escritor cujas exéquias fúnebres, em 1900 (no seguimento das jornadas camonianas de 1880, plenas de significado neste sentido), constituíram a glorificação final desse modelo de intelectual oitocentista que não ultrapassou as marcas de uma respeitabilidade individual e os marcos de uma esfera essencialmente literária.

Ora, voltando ao ponto terminal desse percurso e segundo creio poder ler-se na sugestão do nosso maior escritor realista, parece ter sido na iminência de perda dos sacrossantos valores a que em A Correspondência de Fradique Mendes chamou "a virtude e o espírito" do homem culto burguês oitocentista e ante "a condição quase regular" de crise da Europa $^{(7)}$ que o perfil desse intelectual finissecular nos surge à distância crítica da ironia. Nesse contexto, que não é meramente ficcional, o "homem de letras" - para além do carácter diletante que ressuma da leitura dessa

(4) Vide J. Habermas, ob. cit., p. 40.

(5) Estudos actuais de Paulo Jorge Fernandes, destinados à sua dissertação de doutoramento, mostram como essa matriz de dupla promoção intelectual e política se desenhou, entre nós, a partir da década de 1860 e decisivamente se construiu na década de 1870 como derradeiro modelo romântico-liberal de intervenção pública dos intelectuais.

(6) Vide Alberto Ferreira, Estudos de Cultura Portuguesa (Século XIX), Lisboa, Moraes Ed., 1980, pp. 133-142.

(7) Eça de Queirós, "A Europa", O Repórter, Lisboa, n 79, 20 Mar. 1888, p. [1]. 
apócrifa correspondência e da imaginária biografia fradiquista que a acompanhou - definia-se, não tanto expressamente pelo que houvera sido ou feito, mais pelo que implicitamente o cotejava já com a potenciação de um capital simbólico com juros no futuro: "Não há em mim infelizmente (escrevia ele a Oliveira Martins, em 1882) nem um sábio, nem um filósofo. Quero dizer, não sou um desses homens seguros e úteis, destinados por temperamento às análises secundárias que se chamam Ciências, [...] nem sou também um desses homens, fascinantes e pouco seguros, destinados por génio às análises superiores que se chamam Filosofias"(8).

Num quadro estrutural de rápida evolução das actividades intelectuais que acompanhou o crescimento do clima empresarial e das tendências do Estado burocrático até ao regime republicano e durante este, a figura do cientista (sábio e filósofo, ao mesmo tempo, com uma postura, um discurso e uma prática de rigor e racionalidade a que não foi estranha a implantação do positivismo) foi a que, finalmente, veio a acrescentar ao intelectual romântico e liberal o capital do reconhecimento público de um papel directamente desempenhado nos progressos gerais da sociedade. Desde o último quartel do século XIX, desenvolvera-se justamente um conjunto de fenómenos que geraram entre si efeitos multiplicadores de crescimento cultural, desembocando e prosseguindo na I República: entre outros aspectos, o progresso significativo do jornalismo industrial e das sociedades editoriais com tiragens populares, o crescimento das escolas públicas e das universidades e politécnicas que asseguraram a reprodução geral de quadros médios e superiores, o aumento do funcionalismo burocrático e das profissões liberais, ampliaram consideravelmente a "esfera profissional" que envolveu cada vez mais diversificadas categorias intelectuais e seus efectivos, a par de um público também mais vasto ${ }^{(9)}$. Ora, a crescente importância de um saber especializado nas actividades sociais em geral alimentou a ideia de autonomização dessa intelligentsia em relação aos demais estratos cultos da burguesia em geral, contrapondo especialmente à elite tradicional (de um modo geral, o academismo) a nova expressão de uma elite de especialistas.

\footnotetext{
(8) Idem, A Correspondência de Fradique Mendes.

(9) Vide J. Habermas, ob. cit., p. 162.
} 


\section{A elite: primeira expressão moderna dos intelectuais como grupo}

Entre nós, a marca distintiva do cientista tomou relevo público na figura do técnico que, na atmosfera de meritocracia difundida na república demoliberal, depressa se preconizou membro da nova elite esclarecida e encontrou, no contexto do impasse entre a reacção de uma República Nova e a reiteração de uma Nova República Velha e perante a crise dos valores republicanos instituídos, as condições para pronunciar a eficácia dessa elite. Os intelectuais reclamaram-se, pois, portadores de uma consciência crítica simultaneamente mediadora e mobilizadora - critério de validação desta nova intelligentsia -e, através dela, capazes de desempenhar um papel ético e pedagógico único e insubstituível nas propostas de regeneração nacional. Não pode, aliás, perder-se de vista que, até finais da década de 1930, tanto à esquerda como à direita, a nova intelectualidade, que desdobrou para o campo político uma actividade distinta do campo profissional ${ }^{(10)}$ - reunida em torno de programas, de manifestos, de círculos, de grupos de pressão, de órgãos literários - teria o espectro da ineficácia do regime republicano como horizonte de reflexão e de intervenção política.

$\mathrm{Na}$ trajectória da esquerda intelectual que aqui interessa especialmente encontrar neste período, o ideário seareiro dos anos vinte construiu-se a partir da fundamentação de uma crítica ao status republicano, desde os seus traços mais fundos, isto é, a partir do "momento em que a crise da Cidade acarreta a crise da Educação" (11). Os intelectuais reunidos em torno da revista Seara Nova sentiram-se, pois, enquanto grupo, convocados como alternativa ético-social ao regime republicano - assim se lê nesse verdadeiro manifesto que constituiu o editorial de lançamento: "Todo o país tem de aceitar a responsabilidade que lhe cabe no desastre colectivo; todo o país e em especial a sua elite. A vida política de uma nação é, em grande parte, o reflexo da sua vida intelectual, dos seus movimentos de ideias, das aspirações mais profundas do seu escol"(12).

(10) Vide Christophe Charle, Naissance des "Intellectuels". 1880-1900, Paris, Édit. du Minuit, 1990 (sobretudo cap. 3).

(11) António Sérgio, "Educação e Filosofia", in Ensaios, t. I, Rio de Janeiro/ Porto, 1920, p. 119.

(12) [Raúl Proença], "[Editorial]”, Seara Nova, Lisboa, n 1, 15 Out. 1921. 
Uma vez instalado o regime, os republicanos limitaram-se à "conquista do poder político"! - foi a crítica dos seareiros ("[...] E foi tudo: para os verdadeiros problemas ninguém olhou; nos alicerces da Democracia não pensou ninguém" (13) ) -, não curando "considerar a nação de que somos parte e os grandes factores do seu destino"(14). Era, pois, chegado o momento de reclamar o poder da inteligência. Confiantes na revolução do espírito, os intelectuais desse novo escol desenvolveram nas páginas da Seara Nova um paradigma de envolvimento das consciências livres e elevadas na preparação e construção da obra regeneradora da pátria: "A Seara Nova representa o esforço de alguns intelectuais, alheados dos partidos políticos mas não da vida política, para que se erga, acima do miserável circo onde se debatem os interesses inconfessáveis das clientelas e das oligarquias plutocráticas, uma atmosfera mais pura em que se faça ouvir o protesto das mais altivas consciências $[\ldots]^{\prime \prime(15)}$.

Propondo-se instaurar "o processo de todos os escândalos" e a estes contrapor as "respostas necessárias à vida nacional", os intelectuais republicanos de matriz socialista - se procuraram ir mais longe, até onde a regeneração se traduzisse numa reforma das mentalidades, para a prossecução da qual já muitos haviam militado, em anterior envolvimento no movimento da Renascença Portuguesa, na campanha de universidades populares segundo a tradição do pedagogismo francês - não ultrapassaram, porém, os limites do mais estrito apostulado intelectual, teórico e especulativo, como condição de saber técnico. Esta apoteose do saber teria, aliás, na própria Seara Nova uma dignidade orgânica, precisamente como "[...] um órgão supremo da consciência nacional que fizesse a grande política especulativa e fosse a chama ardente e pura que mantivesse na nação o interesse sempre vivo pelas questões nacionais, que guardasse vigilante os interesses do país e propagasse as grandes verdades salvadoras"(16).

E, ao aparecerem nas colunas desta tribuna, proclamaram as excelências da missão única a que vinham a público: "Se os senhores políticos compreendessem as maiores necessidades do país que governam ou

(13) António Sérgio, "Prefácio", in Ensaios, ed. cit., p. [16].

(14) Idem, ibidem, p. [11].

(15) [Raúl Proença], "A", Seara Nova, Lisboa, nº 1, 15 Out. 1921.

(16) Raul Proença, "A União Cívica e a 'Seara Nova'", in Páginas de Política (1921-1924), Lisboa, 1939, p. 277. 
pretendem governar, diriam ao aparecermos em público: 'Ora até que enfim! Era isso mesmo que nos faltava!'"(17).

Foi esse o fundamento (e pelos mesmos motivos) da confiança que os intelectuais da Seara Nova - Raúl Proença, de entre eles o mais combativo, sustentou até à exaustão - colocaram na formação de uma segunda Câmara da república. Se se não tratava de um "corporativismo" à velha maneira de Oliveira Martins, seria a "uma assembleia técnica, em parte profissional, em parte científica, uma câmara de competências" que se colocava a resolução das reformas do país, pois aos técnicos competiria, em exclusivo, orientar "sobre os métodos, os meios, as minúcias, os pormenores de efectivação de qualquer princípio reformador" ${ }^{\prime \prime 18)}$. Neste sentido, a intelligentsia seareira colocava-se como verdadeiro "partido dos intelectuais" - isso mesmo que, a propósito de uma remodelação governativa, em 1923, se reúne debaixo dos "verdadeiros valores da elite" - "não só literatos, não só artistas, não só eruditos - mas sobretudo homens que tenham a capacidade das ideias gerais, o interesse das questões políticas"(19). Dir-se-ia, acima ou ao lado dos partidos tradicionais, "acima ou ao lado dos governos", constituir o "grande troço da élite agissante, ligada por uma salvadora 'fórmula de aliança'" em "uma espécie de Senado em que se congreguem todos os elementos de orientação intelectual"(20).

\section{Consciência histórica e nova praxis: o "papel dos intelectuais"}

É conhecido como, na transição para os anos trinta, a partir dos ideais seareiros de reforma, a crítica aos limites da actuação da elite se evoluiu para uma perspectiva marxista ${ }^{(21)}$. Pois a segunda ruptura com o paradigma

(17) Idem, ibidem, p. 279.

(18) Idem, "Algumas palavras de proémio", in Páginas de Política, ed. cit., p. 65.

(19) Idem, "'Seara Nova' - Remodelação", in Páginas de Política, ed. cit., pp. 255-256.

(20) Idem, A União Cívica e a "Seara Nova", ed. cit., pp. 262 e 267.

(21) Vide Luís Augusto Costa Dias, Uma Anti-Seara em "Seara Nova". Doutrina e Crítica nos Jornais e Revistas Juvenis da Década de 1930, Coimbra, Centro de Estudos Interdisciplinares do Século XX, 2002 (Cadernos do Ceis20, 3); António Pedro Pita, A Recepção do Marxismo pelos Intelectuais Portugueses (1930-1941), Oficina do 
demoliberal clássico ocorrida no pensamento da esquerda deve registar-se ainda no âmbito de uma republicanização da república que, na cultura nos anos trinta, correspondeu à identificação de uma crise da consciência intelectual e, deste modo, caucionou o rápido desenvolvimento de uma "filosofia da praxis" de raiz marxiana: Bento de Jesus Caraça, matemático e professor do Instituto Superior de Comércio, foi o seu filósofo da cultura. Desvalorizando a noção de elite (ou, antes, procurando inverter o seu papel social determinante na construção do devir histórico) como factor constante de um novo pensamento político-social, o autor da célebre conferência sobre $A$ Cultura Integral do Indivíduo - Problema Central do Nosso Tempo, procedeu a uma leitura segundo a qual era a homens (indivíduos) e não a técnicos que cumpria transformar a sociedade (o colectivo) e, desse modo, cortou radicalmente qualquer compaginação dos postulados seareiros.

Pois, em nota complementar acrescentada à publicação dessa conferência, ao aprofundar o problema do controlo dos meios de produção, veio a clarificar por extenso: "Quer dizer, o problema fundamental é, não um problema de técnica, mas um problema de moral social. E não é aos técnicos que se pode entregar a sua resolução. É a homens" (22).

A crítica ao ideal seareiro assente na oposição entre a elite esclarecida e a massa ignara estabeleceu-se, porém, a partir do papel central atribuído ao conhecimento, gnoseológica e sociológicamente considerado, no processo de desenvolvimento (ou despertar) da consciência colectiva. Porque "o problema fundamental" se tornara "um problema de moral social", os intelectuais deveriam assumir o estatuto de mediadores do conhecimento, transportando (ou seja mediando) o saber especializado para aquele terreno que Caraça designou então por património cultural comum da humanidade, o que permitiria passar (processo de superação) do momento de uma consciência integral (eminentemente individual) para o de uma cultura integral (essencialmente colectiva). Daí podermos

Centro de Estudos Sociais, Coimbra 1989; idem, "O marxismo na constituição ideológica e política do Partido Comunista Português", Revista Crítica de Ciências Sociais, Coimbra, nº 40, Out. 1994, pp. 89-108.

(22) B. J. Caraça, "A Cultura Integral do Indivíduo-Problema Central do Nosso Tempo" (1933), in Cultura e Emancipação, Porto, Campo das Letras, 2002 (Obra Integral de Bento de Jesus Caraça, Edição Crítica, vol. 1), p. 121, subl. do A. 
reconhecer que a dualidade estabelecida entre cultura e emancipação era tomada como condição para um estádio de superior unidade ${ }^{(23)}$.

A emancipação tinha por chave, num mundo em crise, a capacidade de despertar a consciência colectiva das massas para agir, isto é travar uma luta ideológica generalizada a partir das mais profundas condições individuais em que a consciência remete simultaneamente para o encontro do homem consigo próprio e com a comunidade. Ora, de acordo com o universo conceptual que era o do próprio Caraça, a crise da sociedade consistia na contradição, que entendia então no seu limite, entre o estado da infraestrutura e as condições superestruturais, nomeadamente ao afirmar que "a crise é tanto mais violenta quanto maior a desproporção entre a decrepitude das formas e a viveza de ritmo na vida que essas formas devem conter"(24). Nesse sentido, pois, "aquilo que estamos actualmente vivendo e sofrendo não é apenas uma borbulhagem fugaz, destinada a passar como tantas coisas passam, sem deixar sinal; é, muito pelo contrário, uma época de transição, uma ponte de passagem entre aquilo que desaparece e o que vai surgir"(25).

Uma vez, porém, que qualquer perspectiva determinista da história não é a sua - já que, viria a esclarecer com nítida referência: "Não há fatalidade em história. O que acontecerá ... é sempre determinado pelo jogo dos elementos em presença. [...] Aquilo que tem de ser não é ainda, e, como tal, pode vir a não ser"(26) - Caraça pode considerar que a razão não está em crise:

"Na realidade, nem a razão, instrumento supremo[,] nem a vontade de justiça estão em crise. O que está em crise na Europa e no mundo é a estimação dos meios de impor a razão e de realizar a justiça, superestruturas dum mundo social cujas bases se decompõem rapidamente"(27).

(23) Vide A. P. Pita e L. A. Costa Dias, "Bento de Jesus Caraça: um universo intelectual entre a emancipação e a cultura" (introd.), in Bento de Jesus Caraça, Cultura e Emancipação, Porto, Campo das Letras, 2002 (Obra Integral de Bento de Jesus Caraça, Ed. Crítica, 1), especialmente pp. 31-39.

(24) Idem, "Escola Única" (1935), in Conferências e Outros Escritos, Lisboa, 1970, p. 131.

(25) Idem, A Cultura Integral do Indivíduo [... ], cit., p. 66. 1971.

(26) Idem, "A Arte e a Cultura Popular", in Conferências e Outros Escritos, Lisboa,

(27) Idem, A Cultura Integral do Indivíduo [...], cit., p. 66. 
Compreende-se, pois, que nessa possibilidade instrumental de "impor a razão" para "realizar a justiça" (porém, fora de concepções imanentistas que Caraça teve ensejo de criticar no pensamento da época), residia a grande tarefa ideológica moderna orientada para o já vimos ter definido como "despertar colectivo das massas". É justamente este racionalismo que vale a pena desenvolver nos aspectos que informam a proposta de uma verdadeira teoria do conhecimento à luz da qual o nosso conferencista confere ao "papel do intelectuais" um novo estatuto na relação da elite com as massas.

Ora para o pensamento de Caraça, conforme deixou enunciado numa das suas primeiras conferências, a razão constitui uma condição ontologicamente humana e, desde a sua origem, condição emancipadora dos homens em relação à natureza de que fazem parte. São assim terminantes as palavras de abertura dessa palestra de 1931:

"O Homem encontra-se sobre a Terra, não por qualquer acto especial da natureza, mas como resultado duma lenta e progressiva evolução a que estão sujeitos todos os seres vivos. Assim, ele foi colocado na sua origem, não numa situação de privilégio, como pretendem certas doutrinas à margem da ciência, mas nas mesmas condições que os outros animais e sujeito às mesmas necessidades primárias - alimentar-se $e$ abrigar-se, resumindo-se estas necessidades numa única essencial conservar a vida"(28).

O que permitiu ao homem libertar-se dessa condição originária consistiu, então, na transformação da experiência em conhecimento:

"O êxito da conservação da vida depende do maior ou menor conhecimento que se tem do meio ambiente e dos perigos que nele se encontram [...]. O homem foi tornando assim a sua vida cada vez mais segura e isso só foi possível por virtude do seu conhecimento cada vez maior do mundo em que vive. A experiência mostrou-lhe então que só um caminho havia para assegurar com êxito a sua conservação - o conhecer quanto mais perfeitamente melhor [...], isto é, a aspiração de um conhecimento cada vez mais completo"(29).

(28) Idem, "As Universidades Populares e a Cultura", in Cultura e Emancipação, ed. cit., p. 69.

(29) Idem, ibidem, pp. 69-70. 
Pode assim dizer-se que, libertado de uma experiência apenas limitada ao quadro da natureza que é o dos impulsos mecânicos comuns aos outros animais e mergulhado já nas relações e exigências dos agregados primitivos, o conhecimento da experiência começa por ser experiência consciente. Em posterior e, aliás, célebre conferência, o autor viria a precisar essa origem "num estado de existência em que o indivíduo mal tem consciência de si, fundindo-se no agrupamento de que depende" ${ }^{\prime \prime 30}$. É, portanto, sob a forma de uma tomada de consciência que o processo do conhecimento inaugura a aventura humana, sendo certo que em determinadas condições "primárias" de existência.

Ora, de modo correlato, Bento Caraça conduz-nos a considerar que, para além das "necessidades de ordem material", também as "manifestações artísticas" se definem a partir de uma consciência mediadora, como belo consciente, em resultado do mesmo processo de conhecimento que da "contemplação da natureza" por parte do homem fez nascer "no seu espírito o sentimento do belo". E do mesmo modo, ainda, a ideia de justiça (ou "sentido do belo introduzido nas relações sociais") corresponde à cooperação consciente com o agregado, conferindo "ao homem objectivos de ordem moral" a partir da compreensão de que "cada um não deve utilizar as relações de sociedade unicamente com o objectivo de tirar daí interesse ou proveito próprio, deve também dar aos outros o seu esforço para os auxiliar"(31).

Se a aventura humana começa nesse momento da consciência, é que a razão não é justamente estranha, como se viu, ao processo solidário de emergência do conhecimento, do sentimento e da moral na construção da relação do homem com um meio que era já domínio de civilização. E, porque os destinos do homem acarretam inevitavelmente esse progresso, o conhecimento gerado pelo "aperfeiçoamento constante dos meios de satisfação destas necessidades, ideias e sentimentos" conduziu à cultura que é, em suma, um afastamento cada vez maior do estado de natureza de que o homem partiu. A partir de então o conhecimento torna-se, no limite da própria evolução, obra de especialistas, uma vez que " o cultivo e progresso da ciência, bem como a sua aplicação à vida corrente da sociedade, hão-de ser sempre obra de grupos de especializados

(30) Idem, A Cultura Integral do Individuo, ed. cit., p. 102.

(31) Idem, ibidem. 
- prospectores e realizadores", que "existem e existirão, como existem e existirão as elites das outras profissões e actividades" ${ }^{\prime(32)}$-, embora (foi o próprio Caraça que assim o deixou inscrito) no dizer de Marx "compreende o máximo desenvolvimento das capacidades intelectuais, artísticas e materiais encerradas no homem" ${ }^{\prime(33)}$.

Este passo (que no apontamento manuscrito de Bento Caraça nem figura entre aspas, fazendo supor transcrição de algum modo livre) poderia compaginar-se numa leitura de $A$ Ideologia Alemãa, nomeadamente pela referência ao "desenvolvimento das capacidades individuais"(34) - acaso esta obra inacabada de Marx e Engels não tivesse sido somente conhecida em data pouco posterior às conferências que estamos a acompanhar ${ }^{(35)}$. Seja como for, a relação que pode estabelecer-se sugere uma reflexão sobre a importância atribuída à contradição entre civilização e cultura. Porque a consciência não se encontra de modo algum desligada das condições materiais da vida humana e da sua organização social, as realizações e aplicações do conhecimento podem tornar-se objecto de apropriação por parte de interesses que contrariam as "aspirações gerais". Quer, então, dizer-se que o conhecimento define, sim, o estado da civilização, isto é:

"O grau de civilização de um povo mede-se pela quantidade e qualidade dos meios que a sociedade põe à disposição do indivíduo para lhe tornar a existência fácil; pelo grau de desenvolvimento dos seus meios de produção e distribuição; pelo nível de progresso científico e utilização que dele se faz para as relações da vida económica"(36).

Mas considera que já não constitui, por si mesmo, um factor de emancipação, pois o conhecimento passou a estar condicionado pelo estado de organização da cultura para o conjunto dos indivíduos, ou seja:

${ }^{(32)}$ B. J. Caraça, A Cultura Integral do Indivíduo, p. 119.

(33) Idem, As Universidades Populares e a Cultura, p. 70.

${ }^{(34)}$ K. Marx e F. Engels, A Ideologia Alemã, Cap. Primº., [IV, 10], in Obras Escolhidas, Lisboa, Ed. Avante, 1982, p. 69.

${ }^{(35)}$ Creio que a $1^{\text {a }}$ ed. de $A$ Ideologia Alemã ( $1^{\text {a }}$ parte) acessível ao nosso país foi a integrada na publicação francesa das Obras Completas (ed. A. Costes, vol. VI, Paris, 1937).

(36) B. J. Caraça, A Cultura Integral do Indivíduo, ed. cit., p. 118. 
"O seu grau de cultura mede-se pelo conceito que ele forma do que seja a vida e da facilidade que ao indivíduo se deve dar para a viver; pelo modo como nele se compreende e proporciona o consumo; pela maneira e fins para que são utilizados os progressos da ciência; pelo modo como entende a organização das relações sociais e pelo lugar que nela ocupa o homem"(37).

Por que motivo ocorre esta contradição entre as condições materiais da civilização e as formas de acesso geral às suas conquistas? Caraça corresponde: "Esta questão põe-nos em frente do problema das elites e das castas e a experiência histórica ensina que sempre que um grupo se diferencia da massa geral da humanidade, por qualquer título, estabelecendo um monopólio de qualquer coisa - ideias, força ou dinheiro fá-lo, não no interesse geral da massa, mas no seu próprio"(38). E daí: "À pergunta feita deve responder-se portanto condenando a detenção da cultura como monopólio de uma elite"(39).

Compreende-se a importância e alcance radical da afirmação no quadro do pensamento político e social português da sua época. Mas o que pretende, mais profundamente, significar é que não é já o conhecimento (e uma consciência de si individual), mas a cultura (em que aquela se prolonga numa consciência universal como "organismo vivo e uno") factor de emancipação geral, uma vez que importa estabelecer a mais íntima correspondência entre as "aspirações gerais" que o conhecimento interpreta e "as circunstâncias do momento". Isto é, cada passo dado nos níveis do conhecimento e do progresso em geral representa "um novo passo no sentido de subtrair o colectivo à tirania do individual" sem, por isso, no entanto, se concretizar numa elevação das massas cuja "falta de preparação cultural" lhes não permite o "reconhecimento de si mesmas" ${ }^{\prime(40)}$.

Ora, na filosofia da cultura desenvolvida por Bento Caraça, que é simultaneamente um modelo interpretativo e operativo - conhecimento e praxis -, a acção emancipadora da humanidade carece então do trabalho de mediação de uma nova consciência ou "reconhecimento de si".

\footnotetext{
(37) Idem, ibidem.

(38) Idem, As Universidades Populares e a Cultura, p. 71.

(39) Idem, ibidem.

(40) Idem, A Cultura Integral do Individuo, p. 105.
} 
Daí esta interrogação sobre o momento de crise que a si mesma se responde:

“Conseguirá a Humanidade, num grande estremecimento de todo o seu imenso corpo, tomar finalmente consciência de si mesma, revelar a si própria a sua alma colectiva, feita do desenvolvimento ao máximo, pela cultura, da personalidade de todos os seus membros?"(41).

Tal é o momento em que a cultura se torna "simultaneamente um meio e um fim"(42), reivindicada "para a colectividade inteira, porque só com ela pode a humanidade tomar consciência de si própria, ditando a todo o momento a tonalidade geral da orientação às elites parciais" ${ }^{\prime(43)}$. A consciência desta historicidade só pode implicar um trabalho imenso e radical na construção de uma consciência culta. Tarefa imensa: "O que o mundo for amanhã, é o esforço de todos nós que o determinará"(44). E tarefa radical porque era esta a cena da história de que Bento Caraça via "os indícios precursores" numa das suas primeiras intervenções públicas: "Creio que a classe operária está destinada a, num futuro mais ou menos próximo, tomar nas suas mão a direç̧ão dos destinos do mundo, transformando por completo toda a organização social existente"(45).

Vejamos como, neste texto de rara explicitação ideológica (muito recentemente restituído à sua integral textualidade e precisa contextualidade), se fixava a filosofia da História de Caraça. Pois, ao definir esse novo momento da consciência enquanto histórica viragem no devir social, baseou na noção de "missão histórica" aqueles "indícios seguros". Releia-se o texto de 1930:

"A classe actualmente dominante e dirigente deu as suas provas, desempenhou na evolução política e social o papel que lhe competia, cumpriu a sua missão histórica. Olhemos para ela com o respeito que the é devido pelo que de bom trouxe à humanidade e, após esse preito de justiça, encaremos o presente e preparemos o futuro"(46).

(41) Idem, ibidem, p. 114.

(42) Idem, As Universidades Populares e a Cultura, p. 70.

(43) Idem, A Cultura Integral do Individuo, p. 119.

(44) Idem, ibidem, p. 99.

(45) Idem, "Os Objectivos da Universidade Popular Portuguesa", in Cultura e Emancipação, ed. cit., p. 61.

(46) Idem, ibidem, p. 62. 
E tem para esse diagnóstico a resposta, ao afirmar, na mesma sintaxe ideológica tirada do aprendizado mais clássico de uma leitura marxiana, as condições da nova missão revolucionária: "O sistema capitalista traz a morte no flanco. $\mathrm{O}$ agravamento das suas contradições leva-o ao extermínio de si próprio e cria ao lado da classe burguesa uma outra cada vez mais poderosa e mais desperta, a proletária, que se ergue como um jovem gigante para dominar o mundo".

Classe cada vez mais desperta, no sentido histórico-social, urgia organizar esse despertar, na acepção ético-social que facilmente se reconhece em Caraça e que correspondeu a uma "via única - trabalhar para que o espírito de justiça, que já vimos condenar a actual classe dirigente, não tenha que vir a condenar também a futura". O legado humanista de Bento Caraça, de funda e progressiva raiz iluminista, de uma "crença" que era "bem viva e bem forte - a crença na perfectibilidade humana", actualizava-se na necessidade de estabelecer como tarefa cultural do momento histórico a de "preparar a classe operária para o desempenho da sua missão - o estabelecimento da justiça sobre a terra" (47).

Era esta tarefa de organização da cultura que deveria competir aos intelectuais, num trabalho revolucionário (numa conferência de que mais não restou que apontamento manuscrito, falou explicitamente de cultura proletária) que só as "elites parciais", como especialistas de saberes vários e sob a orientação da tonalidade geral dada pela nova classe revolucionária, poderiam assumir como "papel" social específico. É que, para além de um produtor especializado de conhecimento capaz de realizar, através de um trabalho de selecção e de síntese, o sentido do todo das ideias com as condições reais existentes ${ }^{(48)}$ - o "papel dos intelectuais" que Caraça define como característico e insubstituível para a construção da consciência do momento reside neste tópico de uma conferência proferida em 1931 para uma audiência de operários: "O homem perante a sociedade - necessidade da sua emancipação e causas dessa necessidade. A cultura tem estado ao serviço de toda a humanidade? Qual tem sido o papel dos intelectuais? O que há a fazer - cultura proletária"(49).

(47) Idem, ibidem, pp. 62-63.

${ }^{(48)}$ Vide A. P. Pita e L. A. Costa Dias, pref. cit., p. 39 ss.

(49) Trata-se da conferência sintomaticamente intitulada Cultura e Emancipação, que levou, com justos motivos, a designar com o mesmo título o primeiro volume da Edição Crítica da Obra Integral de Bento de Jesus Caraça (vide o rascunho do texto, ed. cit., pp. 162-163). 
Estas interrogações remetem para idênticas outras que, a respeito da função social das elites ao longo da vasta aventura humana, o nosso filósofo da cultura colocou ao refutar, no célebre texto sobre $A$ Cultura Integral do Individuo, toda a matriz individualista que separa "o florescimento das ciências, das letras e das artes" como "obra de uma elite, mais ou menos reduzida" do acesso da "massa geral da humanidade". Leiam-se as interrogações, pertinentes para aferir o verdadeiro reconhecimento da função dos intelectuais: "[...] as elites propulsoras, em cada período histórico, do desenvolvimento científico, literário, artístico, foram realmente aquelas que, nesse período, ditaram a forma de constituição da sociedade, a orientaram, regularam o seu funcionamento orgânico? por outras palavras, elite científica e cultural e classe dirigente, são a mesma coisa? ou, melhor ainda, a primeira está compreendida na segunda?"(50).

O autor não hesita em responder de imediato "pela negativa", acusando o facto de que, no limite das suas funções de entrega à verdade ou à beleza, pende sobre os intelectuais o espectro de uma proletarização (que acompanhava a "proletarização de vastas camadas da população de todo o mundo"(51)); ou, pior, os "queixumes e protestos com que aqueles homens verdadeiramente de elite, aqueles que, alguns séculos mais tarde, dão o tom ao mundo da alma e do pensamento, respondem às perseguições que os seus contemporâneos das classes dirigentes lhes movem". Daí que o universo conceptual de Bento Caraça determine com nitidez uma distinção, para lá da coerência unitária que o autor pretende atingir em suma, entre o trabalho intelectual, a sua função social e o papel cívico dos intelectuais. Aqui, busca determinar-se apenas este último aspecto, que é, como procurei assinalar de início, na história dos intelectuais o marco distintivo do século XX.

O que Caraça espera que corresponda ao "papel dos intelectuais" na consciência do momento é, então, a adesão a uma nova consciência de classe; ao menos, implicitamente, como tarefa mobilizadora. Esta é a mais nobre função mediadora entre a produção da cultura e o enriquecimento da humanidade: "é a coragem de assumir a responsabilidade de soluções capazes de integrar mais profundamente a Razão e a Justiça na existência comum dos homens" ${ }^{\prime(52)}$ - que significa, na recusa de qualquer

\footnotetext{
${ }^{(50)}$ B. J. Caraça, A Cultura Integral do Individuo, cit., p. 115.

(51) Idem, ibidem, p. 112.

(52) Idem, "Crepúsculo da Europa", in Cultura e Emancipação, ed. cit., p. 96.
} 
imanentismo, dar um novo sentido do todo aos três grandes princípios originários da condição humana que são, como vimos, o conhecimento, o sentimento do belo e a vontade de justiça.

O compromisso que, como intelectual, Bento de Jesus Caraça pretendeu assumir designou-o explicitamente nas palavras de abertura da sua célebre conferência de 1933 a convite do grupo Mocidade Livre: "Quero afirmar aqui a minha inteira solidariedade com estes moços que pretendem compreender e viver o seu tempo e trazer-lhes, do mesmo passo, a minha modesta contribuição"(53).

Ser do seu tempo, possuindo uma consciência da historicidade - a de se estar pensando e fazendo de acordo com as exigências da sua época -, implicou ainda para Bento Caraça a humildade da adesão a uma consciência histórica precisa - a de se estar construindo para lá do seu tempo, de acordo com as exigências do devir em toda a dimensão doutrinária. Daí esta demonstração, com que encerra justamente essa conferência de 1933, da necessidade de uma consciência ética sobre o futuro no horizonte das transformações que no presente se preparam: "E não queiramos que amanhã tenham de praticar para connosco esse gesto, impiedoso mas justiceiro, exactamente o mesmo que hoje nos vemos obrigados a fazer para com aquilo que, do passado, é obstáculo no nosso caminho"(54).

Daí, finalmente, a importância da cultura no terreno da qual se opera a síntese da consciência integral de cada homem culto (consciência revolucionária no "conhecimento completo de todos os seus direitos e de todos os seus deveres") numa cultura integral (consciência integradora de cada um numa totalidade mais vasta, até à "realização do bem comum" nas suas últimas consequências) em que a todos se coloca esta superior tarefa revolucionária:

"Revolucionária ainda e sobretudo no sentido de que, preparando científica e moralmente a classe operária para o desempenho da missão futura que the incumbe, a torne bem consciente do seu dever último e supremo-o do seu próprio desaparecimento num futuro mais ou menos longínquo em que não deve haver classes mas apenas homens livres"(55).

\footnotetext{
(53) Idem, A Cultura Integral do Individuo, p. 99.

(54) Idem, ibidem, p. 120.

(55) Idem, Os Objectivos da Universidade Popular Portuguesa, p. 64.
} 